\title{
Cell structure and percent viability by a slide centrifuge technique
}

\author{
MARGARET G FITZGERALD, CS HOSKING \\ From the Immunology Department of Royal Children's Hospital, Parkville, Victoria 3052, Australia
}

SUMMARY It was found that a slide centrifuge (Cytospin) preparation of a cell suspension allowed a reliable assessment of not only cell structure but also the percentage of non-viable cells. The nonviable cells appeared as "smear" cells and paralleled in number the cells taking up trypan blue. Direct experiment showed the unstained viable cells in a trypan blue cell suspension remained intact in a Cytospin preparation while the cells taking up trypan blue were the "smear" cells. The non-viability of the "smear" cells was confirmed by their inability to survive in culture.

Centrifugal force applied to cells in suspension flattens them onto a glass slide in a monolayer with a minimal risk of cellular damage. ${ }^{12}$ At the same time the cells are concentrated onto a small area of the slide thus facilitating a more convenient and precise investigation of fluids with a low concentration of cells. ${ }^{134}$ Slide centrifuge equipment was originally developed independently by Doré and Balfour ${ }^{5}$ and by Watson. ${ }^{1}$

Trowell ${ }^{7}$ and Thomson, ${ }^{89}$ in experiments on smeared lymphocyte preparations, suggested that viable cells could be differentiated from non-viable by their nuclear structure. Bhuyan ${ }^{10}$ compared several functional methods of assessing cell viability but did not relate this to the morphology of the cells.

In experiments where both viability and structure of a cell preparation required assessment, we used vital dye exclusion (trypan blue) to estimate viability and a slide centrifuge (Cytospin) preparation of the cells allowed examination of cell structure. The Cytospin preparation showed "smear" cells which appeared equivalent in numbers to the non-viable cells taking up the trypan blue. It became apparent that percent viability ascertained in this manner from the Cytospin preparation paralleled that of the trypan blue technique. Confirmation was sought to validate this method of viability estimation. The findings are presented in this paper.

\section{Material and methods}

TRYPAN BLUE DYE EXCLUSION Cells at a concentration of approximately $1.5 \times$

Accepted for publication 30 June 1981
$10^{6} / \mathrm{ml}$ were added to trypan blue solution $(0 \cdot 12 \%$ in normal saline) at a volume : volume ratio of $1: 4$. Percent viability was determined in a haemocytometer chamber as the number of cells excluding the dye per 100 counted.

\section{CYTOSPIN PREPARATION}

The microscope slide cell preparations were made in a Shandon-Elliott Cytospin (Shandon-Elliott Instruments Limited). Each cuvette was loaded with $20 \mu \mathrm{l}$ of protein-containing medium in which was suspended $0.5 \times 10^{5}$ to $5.0 \times 10^{5}$ cells. Centrifugation was performed for $5 \mathrm{~min}$ at $1000 \mathrm{rpm}$ for cells of a mouse myeloma line. The slides were fixed in methanol for $1 \mathrm{~min}$ then stained for $5 \mathrm{~min}$ with Giemsa stain (Gurr's Improved R66) 1/5 in phosphate buffer $\mathrm{pH} 6 \cdot 8$. The number of "nonsmear" cells per 100 cells counted was the measure of viability.

\section{CYTOTOXICITY AND VIABILITY}

A mononuclear cell preparation from human blood was obtained by Ficoll/Isopaque (F/I) density gradient separation ${ }^{11}$ and the cell numbers made up to $2.5 \times 10^{6} / \mathrm{ml}$ Dulbecco phosphate-buffered saline (PBS). To $200 \mu \mathrm{l}$ of this cell suspension was added $100 \mu \mathrm{l}$ of doubling dilutions of sheep antithymocyte antiserum (ATS) for $30 \mathrm{~min}$ at room temperature. The supernatant was removed to $250 \mu$ l. The cells were resuspended: $50 \mu \mathrm{l}$ was used for the trypan blue dye exclusion and $200 \mu \mathrm{l}$ for the Cytospin preparation. Percent viability was determined per 100 cells for trypan blue dye exclusion and per 400 or 500 cells for the Cytospin preparation.

ATS was double diluted in PBS from 1/10 to 
$1 / 1280$. Controls included a tube without ATS (0) and a tube with fetal calf serum only (FCS). The curve was prepared on three occasions $(1,2,3)$ from the cells of one control person and once (4) from the cells of a second control.

VIABILITY AND GROWTH POTENTIAL

The mouse myeloma line Pl-BU2 is seeded routinely in our laboratory at $0.25 \times 10^{6}$ cells/ml RPMI 1640 (Gibco) with $20 \%$ FCS and incubated at $37^{\circ} \mathrm{C}$ for 3-4 days resulting in growth to $1.5-2.0 \times 10^{6}$ cells $/ \mathrm{ml}$ at $95-100 \%$ viability. However three cultures were seeded at varying higher concentrations and incubated for 5 days to give cell suspensions of different viabilities. From a culture grown to $1.5 \times 10^{6} \mathrm{cells} / \mathrm{ml}$ at $99 \%$ viability, culture 1 was seeded at $0.37 \times$ $10^{6}$ cells $/ \mathrm{ml}$, culture 2 at $0.43 \times 10^{6}$ cells $/ \mathrm{ml}$ and culture 3 at $0.5 \times 10^{6}$ cells $/ \mathrm{ml}$.

After 5 days incubation, $50 \mu$ l was removed for trypan blue dye exclusion and $25 \mu$ l for a Cytospin preparation. Then each $5 \mathrm{ml}$ culture was underlayered with $1.5 \mathrm{ml} \mathrm{F/I} \mathrm{and} \mathrm{centrifuged} \mathrm{for} 10 \mathrm{~min}$ at $700 \mathrm{~g}$. The cells at the interface (between medium and $F / I$ ) and the cells in the pellet were collected separately and washed. Viability was reassessed. Cultures from each interface and pellet suspension were seeded at the routine concentration of $0.25 \times$ $10^{6}$ cells $/ \mathrm{ml}$. Viability was determined after 4 days incubation. (Flow chart in Fig. 1).

Percent viability was assessed by counting 100 or 200 cells of the trypan blue preparation and 100 cells on the slide.

TRYPAN BLUE-CYTOSPIN

Three cultures with varying viability were obtained for the mouse myeloma line P3 NSI/1-Ag4-1 (NSI) by seeding at different concentrations and culturing at $37^{\circ} \mathrm{C}$ for different periods. NSI was seeded at the usual ratio of 1 : 50 with a 4-day culture period and in addition at the higher ratio of $1: 5$ being cultured for both 4 and 7 days.

The trypan blue-Cytospin preparation consisted of $20 \mu \mathrm{l}$ NSI cells suspended in $100 \mu \mathrm{l}$ growth medium with $100 \mu$ l trypan blue. Two Cytospin preparations from each of the three NSI cultures were fixed in methanol. One was dipped in eosin to visualise the non-staining viable cells while the second was stained with Giemsa enabling cell morphology to be examined. The percentage of trypan blue-positive and -negative cells were scored with the structure and morphology being recorded.

\section{Results}

CYTOSPIN “SMEAR” CELL

The photomicrograph is of a "smear" cell from a

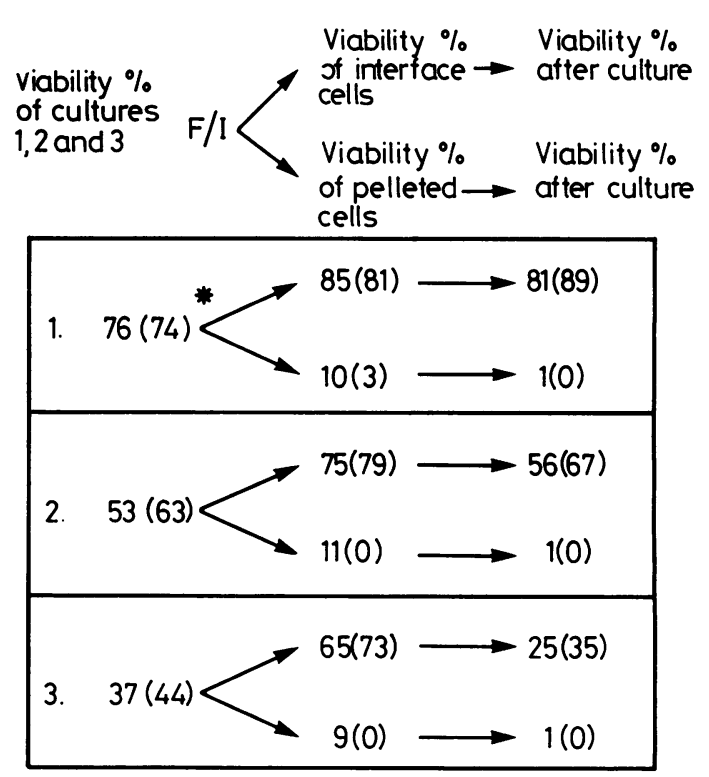

Fig. 1 Viability as determined by Cytospin preparation compared with ability to grow in culture. $76(74)^{*}=76 \%$ viable by trypan blue dye exclusion. (*74\% viable by Cytospin preparation).

Cytospin preparation (Fig. 2). The dead cells appear as homogeneous or granular pink material with no limiting membrane and no obvious nuclear cytoplasm differentiation.

CYTOTOXICITY AND VIABILITY

Figure 3 shows the viability of mononuclear cells after treatment with ATS dilutions. Viability determined by trypan blue dye exclusion is closely paralleled by that ascertained from the "non-smear" cells of Cytospin preparations for the three curves of control 1 and that of control 2 .

\section{REPRODUCIBILITY OF COUNT}

In assessing viability of the Cytospin preparation, the total count was taken after each 100 cells up to a total of 500 cells. The mean of the coefficient of variation of these readings was $7 \%$.

VIABILITY AND GROWTH POTENTIAL

Figure 1 sets out the results for the three cultures of varying viability as determined by trypan blue dye exclusion and then ascertained by evaluating the number of "smear" cells on a Cytospin preparation.

The refractile/"non-smear" cells found at the interface of the Ficoll/Isopaque separation were able to be grown in culture while the blue/"smear" cells of the pellet had no growth potential. Viability is thus associated with the former cell types of both 


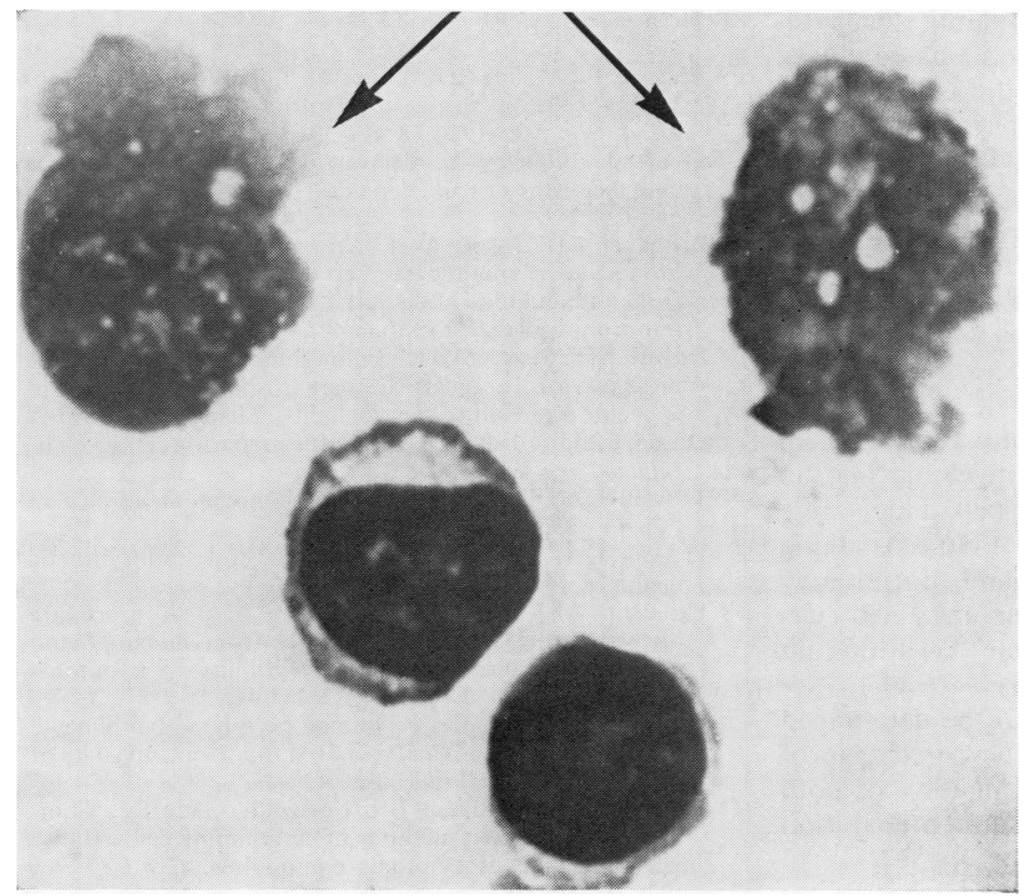

Fig. 2 Cytospin preparation (two non-viable cells indicated by arrow with two viable lymphocytes).

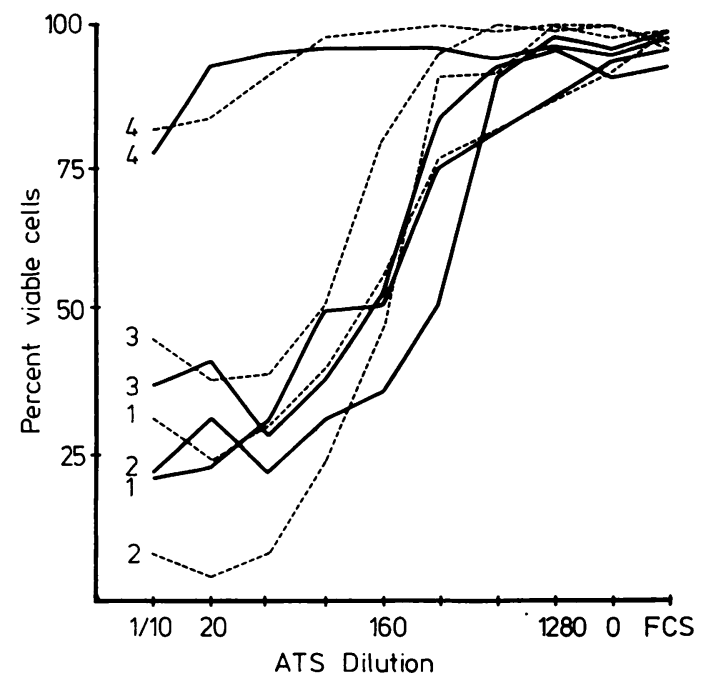

TRYPAN BLUE-CYTOSPIN

Cells with uptake of trypan blue appeared as $8 \%$ in the eosin-stained preparation and $7 \%$ in the Giemsastained preparation $(8 / 7 \%)$ of the low seed -4 day culture of NSI. The higher seed culture grown for 4 days recorded $46 / 45 \%$ (eosin/Giemsa) while that grown for 7 days was $64 / 64 \%$ (eosin/Giemsa). The cells taking up trypan blue were structureless "smear" cells. The trypan blue negative cells had the morphology of the NSI mouse myeloma line.

\section{Discussion}

The initial observation related viability determined by trypan blue dye exclusion with that assessed on morphological grounds from a Cytospin preparation. During fusion experiments in which mouse myeloma cells were mixed with mouse spleen cells in the presence of polyethylene glycol, it was necessary to examine the fusion product for viability and morphology. It became evident that the Cytospin preparation could serve to determine viability and to provide a cytological preparation to detect fusion events. The Cytospin was set for a time and at a force that enabled adhesion of the particular cells without additional trauma. Such a situation of minimal cellular damage was evaluated by Watson. ${ }^{1}$ At speeds from 400 to $1500 \mathrm{rpm}$ cell damage was not extensive. 
A standardised system of estimating the cytotoxicity titre of an ATS preparation was employed to examine whether a correlation did exist between the two methods of viability determination. This proved to be the case (Fig. 3). Evidence was then needed to confirm the non-viability of both the cells taking up dye and the "smear" cells as well as the viability of the refractile and the "non-smear" cells. A system for such an assessment of growth potential was designed using mouse myeloma cells of the P1BU2 line. The finding of this experiment was that "smear" cells are not viable.

A direct confirmatory experiment was undertaken whereby cells of the NSI mouse myeloma line, in suspension and stained with trypan blue, were examined as a Cytospin preparation. No cells taking up trypan blue had the structure and morphology of NSI cells, that is the trypan blue-unstained cells remained intact and only the "smear" cells took up trypan blue.

It would appear that viability can be determined from a Cytospin preparation as the percentage of "non-smear" cells. Hence the examination of both viability and cell structure on the same preparation is a practical procedure.

This study was supported by a grant from the National Health and Medical Research Council. We thank Dr G Tauro for allowing us to use the Sanilon-Elliott Cytospin and Mr I Jack for providing the cells of the mouse myeloma line P1-BU2.

\section{References}

${ }^{1}$ Watson P. A slide centrifuge: an apparatus for concentrating cells in suspension onto a microscope slide. $J$ Lab Clin Med 1966;68:494-501.

${ }^{2}$ Stuart J, Bitensky L, Chayen J. Quantitative enzyme cytochemistry of leukaemic cells. J Clin Pathol 1969;22: 563-6.

${ }^{3}$ Brubaker LH, Evans WH. Separation of granulocytes, monocytes, lymphocytes, erythrocytes, and platelets from human blood and relative tagging with diisopropylfluorophosphate (DFP).J Lab Clin Med 1969;73:1036-41 .

${ }^{4}$ Dayan AD, Stokes MI. Immunofluorescent detection of measles-virus antigens in cerebrospinal-fluid cells in subacute sclerosing panencephalitis. Lancet $1971 ; \mathbf{i}: 891-2$.

${ }^{5}$ Dore CF, Balfour BM. A device for preparing cell spreads. Immunology 1965;9:403-5.

6 Trowell OA. The culture of lymph nodes in vitro. Exp Cell Res 1952;3:79-107.

7 Trowell OA. The culture of lymph nodes in synthetic media. Exp Cell Res 1955;9:258-76.

${ }^{8}$ Thomson AER, Bull JM, Robinson MA. A procedure tor separating viable lymphocytes from human blood and some studies on their susceptibility to hypotonic shocks. Br J Haematol 1966;12:433-46.

${ }^{9}$ Thomson AER. Studies on human peripheral lymphocyte populations in vitro. Sci Basis Med Ann Rev University of London: Athlone Press, 1968:127-46.

${ }^{10}$ Bhuyan BK, Loughman BE, Fraser TJ, Day KJ. Comparison of different methods of determining cell viability after exposure to cytotoxic compounds. Exp Cell Res 1976;97:275-80.

$"$ Boyum A. Separation of leukocytes from blood and bone marrow. Scand J Clin Lab Invest 1968;21, suppl:97.

Requests for reprints to: Dr CS Hosking, Department of Immunology, Royal Children's Hospital, Parkville, Victoria 3052. Australia. 